\title{
THE LEGAL REGULATION OF RELIGIOUS SYMBOLS IN THE PUBLIC SPHERE IN SERBIA
}

\section{DALIBOR ĐUKIĆ}

\section{Introduction}

\subsection{Scope of the research}

This study scrutinises the use of religious symbols in the public sphere and the interplay between the freedom of religion or belief and the right to manifest one's religion through religious symbols. First, there is the question of how religious symbols should be defined. Just as it is difficult to define religion, so it is difficult to determine which symbols should be considered religious. In this paper, religious symbols are symbols related to or inspired by religion. ${ }^{1}$

To write about religious symbols in public spaces, it is also necessary to define the concept of public space. Much has been written on this topic. ${ }^{2}$ Without bringing in too many theoretical concepts, it is enough to say that this study uses the terms 'public space' and 'public sphere' in the broadest possible sense. Public space is outside both the private sphere and the internal domain of religious organisations.

This chapter analyses the legal use of religious symbols in the Republic of Serbia. It covers constitutional and legal regulations related to the right to manifest religious beliefs, relevant case law, and other legal sources, including statutes and regulations.

1 Howard, 2012, p. 27.

2 See Habermas, 1991, pp. 1-14; Emerson, 2018, pp. 286-289.

Dalibor Đukić (2021) The Legal Regulation of Religious Symbols in the Public Sphere in Serbia. In: Paweł Sobczyk (ed.) Religious Symbols in the Public Sphere, pp. 141-170. Budapest-Miskolc, Ferenc Mádl Institute of Comparative Law-Central European Academic Publishing. 


\subsection{Methodology}

The present study analyses and critically interprets Serbian legislation on churches and religious communities, focusing on the use of religious symbols in public spaces and more generally in the public sphere. The historical method is used to determine the circumstances that led to the adoption of certain measures and the meaning of norms at the time they were created and applied. Since the paper analyses applicable law, the historical method is of secondary importance and will only be used to introduce this chapter.

Legal rules are described using doctrinal legal research methodology. This section is followed by a systematic exposition, a comprehensive and detailed analysis, and a critical review of the relevant legal rules, statutory materials, jurisprudence, and legal principles and concepts. The comparative method is used to investigate the interaction and interplay between current legislation in countries with different models of church-state relations.

\subsection{Basic concepts}

The presence of religious symbols in the public sphere relates to the broader issue of the expression of faith or belief in the public sphere. This area is regulated by the constitution, international instruments designed to protect human rights, and laws and bylaws that regulate the freedom of religion. In addition, the freedom to manifest religious beliefs depends on extra-legal factors, including political, sociological, cultural, and religious factors. An interdisciplinary approach makes it possible to consider all aspects of this complex issue.

In accordance with its constitution, the Republic of Serbia is a secular state, separated from churches and religious communities. However, separation does not imply confrontation. This paper will begin by considering the relationship between the constitutional principle of state secularity and the right to manifest religious beliefs in the public sphere.

The position of religion in the public sphere is related to the issue of regulating the relationship between the state and the church. The Serbian system of cooperative separation implies a benevolent attitude towards religious organisations, which has implications for the use of religious symbols in public spaces. Thanks to the state's comprehensive cooperation with churches and religious communities, there is space for the use of religious symbols in public and state institutions, print and electronic media, and state services.

In the Republic of Serbia, there are no regulations that explicitly regulate the use of religious symbols. In fact, the legislature seems to have relied on important actors in the public sphere to independently determine how religious symbols should be used. This approach has not caused tensions, disputes, or conflicts. The paper will scrutinise and present the advantages and disadvantages of such a system, as well as its consequences for religious freedom in the Republic of Serbia. 


\section{The historical, social, cultural, and political context surrounding religious symbols in public spaces}

Until the political changes in 1991, the public expression of religious beliefs in Serbia was limited both de jure and de facto. Of course, state interventionism in this area did not always have the same intensity. In accordance with the regime's ideology, the use of religious symbols was not formally banned. However, religious symbols were banished from the public sphere. For reasons of realpolitik, communist ideologues devised completely new symbols, which did not derive from existing religious or national symbols. ${ }^{3}$ The official intention of the Communist Party was to 'remove' religion from society, but the removal of religion from public life was euphemistically presented as respect for the principle of freedom of religion, 'a personal and private matter for every citizen'. ${ }^{4}$ Religious symbols were removed from schools, universities, and public institutions. The display of religious symbols in public places was a rarity. This militant secularisation of society confined religion to the homes of believers and the premises of religious organisations. The goal was to marginalise churches and religious communities, and to limit their activities to performing rituals and services. ${ }^{5}$

After the disintegration of the Socialist Federal Republic of Yugoslavia, social, political and religious circumstances changed significantly. In 1977, the Law on the Legal Status of Religious Communities became practically inapplicable; it ceased to be valid on 16 March 1993, based on the Law on the Repeal of Certain Laws and Other Regulations. ${ }^{6}$ Because the legal position of churches and religious communities was not regulated, the repeal of the 1977 Law created a legal gap. Newly established religious organisations could acquire legal personalities and regulate their legal positions as simple associations of citizens. ${ }^{7}$ In addition to the legislative gap, there was also a doctrinal one. During communist rule, scientific processing and the development of theoretical conceptions of different systems of relations between the state and the church were neglected. As in many other Central and Eastern European countries, there was also a special problem: the decades-long isolation and lack of insight or deliberate oversight of the modern and balanced solutions that existed in the Western countries on the European continent.

In addition, the adoption of new regulations to protect the freedom of religion was complicated by political circumstances. A striking example was the Draft Law on Religious Freedom adopted in 2002 by the government of the Federal Republic of Yugoslavia. It was never put to a vote in the Chamber of Citizens because, at

\footnotetext{
3 Naumović, 1995, p. 117.

4 The Programme of the League of Yugoslav Communists, p. 253.

5 Radulović, 2014, p. 81.

6 Law on the Repeal of Certain Laws and Other Regulations, art. 1.

7 Avramović, 2007, p. 14.
} 
the end of the debate, the session was abruptly interrupted and never resumed; the Federal Republic of Yugoslavia ceased to exist shortly afterwards. ${ }^{8}$ During that time, several other important issues, such as the question of religious education in public schools, were resolved by passing special laws or individual bylaws. ${ }^{9}$ In the new state, the Law on Churches and Religious Communities was drafted and enacted in 2006, alongside the social framework. ${ }^{10}$ In the same year, the Law on the Restitution of Property to Churches and Religious Communities was passed. ${ }^{11}$ This resolved the issue of reparations for the historical injustice inflicted on churches and religious communities after the Second World War in Serbian territory. While the Law on Churches and Religious Communities restored the legal position, the Law on the Restitution of Property to Churches and Religious Communities created a legal framework for returning property confiscated without just compensation after the Second World War.

Although the legal position of churches and religious communities in the Republic of Serbia was unregulated after 1993, their actual position improved, because society's attitude towards them changed significantly. This change was made visible through the presence of religious symbols in the public sphere. Icons, crucifixes, celebrations of religious feast days, and other expressions of freedom of religion slowly returned to classrooms, public institutions, and other public spaces. This process took place spontaneously and voluntarily. It was not organised or regulated by special legal structures, but depended largely on individuals, who decided at certain moments which symbols would be displayed in public. After the new constitution was adopted in 2006 and a system of cooperation between the state and churches and religious communities was implemented, the use of religious symbols in the public sphere was in some way legalised. Churches and religious communities were given a place in the public sphere, corresponding to their importance in and influence on modern Serbian and European society.

\section{Axiological and constitutional foundations}

The 2006 Constitution of the Republic of Serbia guarantees the right to exercise freedom of thought, conscience, and religion. ${ }^{12}$ The right to freedom of religion is inseparably linked to the right to manifest religious beliefs, which can be exercised through the use of religious symbols, the wearing of characteristic vestments and 
symbols, and the public display of essential elements of religious identity. The public display of religious symbols is based not only on constitutional principles, but also on the social values that underpin the modern Serbian legal system.

\subsection{History and tradition}

Religious symbols are deeply rooted in the history and traditions of the people who live in the territory of the Republic of Serbia. Significant state and national holidays are also religious holidays; their celebration involves the performance of religious rites, with the inevitable use of signs and symbols associated with particular churches and religious communities. ${ }^{13}$ Prohibiting or restricting the use of religious symbols in the public sphere would be contrary to the historical and traditional values of Serbian society. The same statement could be applied to most, if not all, European countries.

\subsection{Religious pluralism}

One of the characteristics of modern Serbian society is religious pluralism. In general, pluralism is integral to democratic societies. ${ }^{14}$ The origins and survival of a democratic society depend on religious pluralism, among other things. Importantly, the Republic of Serbia is an 'autochthonous multi-religious state. ${ }^{15}$ In its religious structure, it resembles many other European countries, although its multireligiousness does not come from immigrants bringing their religions from other countries. Instead, it reflects a population divided into several different religions and denominations. One manifestation of autochthonous religious pluralism is the presence and use of religious symbols associated with traditional churches and religious communities in the public sphere. This not only protects the right of traditional religious organisations to express their religious beliefs, but also helps to democratise society, creating a modern framework of state-church relations. Since religious and ethnic affiliations are often intertwined, ${ }^{16}$ the protection of religious pluralism helps to develop harmonious interethnic relations. In particular, it improves the position of religious and national minorities.

\subsection{The secularity of the state}

State secularity is one of the main principles underpinning the regulation of relations between the state and religious organisations in modern democratic states. In the Republic of Serbia, the principle of secularity is a key constitutional principle.

13 See: http://www.spc.rs/sr/proslava_sretenja_u_ustanichkom_orashcu.

14 Metropolitan Church of Bessarabia and others v. Moldova, application no. 45701/99, para. 119.

15 Radulović, 2014, p. 96.

16 Đurić, 2014, p. 62. 
The first part of the Serbian constitution, which includes constitutional principles, describes Serbia as a secular state (art. 11, the Republic of Serbia is a secular state). This raises the following questions: Do the presence and display of religious symbols in the public sphere violate the principle of state secularity prescribed by the constitution? If so, is it unconstitutional to manifest religious beliefs or display religious symbols in public? According to J. Toron and C. Durham, 'one of the major areas where the difference between secularity and secularism has been evident in various legal systems around the world is in its attitudes toward religious symbols in public space'. ${ }^{17}$

Uncertainties about the meaning of the term 'secular state' in the 2006 Constitution of the Republic of Serbia were resolved by the Constitutional Court, which considered proposals to determine the unconstitutionality of the Law on Churches and Religious Communities. The court ruled that 'these constitutional provisions by themselves do not imply a system of the complete separation of church and state; however, there is no state church and no identification of the state with a particular religion or religion in general.... ${ }^{18}$ Since manifesting religious beliefs in public and displaying religious symbols in public spaces cannot establish a state church or identify the state with a particular religion, it can be argued that such practices do not violate the constitutional principle of state secularity. ${ }^{19}$

\subsection{The principle of separation between the state and churches and religious communities}

The separation of the state and religious organisations is linked to the principle of state secularity. As the Serbian constitution explicitly states, 'Churches and religious communities shall be separated from the state'. ${ }^{20}$ However, although the constitution separates religious organisations from the state, it does not specify the type of separation in question: strict (absolute) or cooperative (relative) ${ }^{21}$ Either way, the presence of religious symbols in state institutions and the public sphere does not establish an institutional unity between the state and religious organisations. For this reason, it does not violate the constitutional principle of church-state separation. The fact that the symbols and signs of various associations, humanitarian organisations, and political parties are displayed in state and public spaces supports this position; there is currently no institutional connection between the state and those entities and none is likely to be established.

17 Toron and Durham, 2015, p. 50.

18 IUz- 455/2011.

19 Calo, 2012, p. 811.

20 Constitution of the Republic of Serbia, art. 11.

21 Avramović, 2011, p. 294. 


\subsection{Establishment clause}

The constitution of the Republic of Serbia stipulates that no religion may be established as a state or mandatory religion. ${ }^{22}$ The ban on establishing a state or obligatory religion is a logical consequence of the constitutional norm that makes Serbia a secular state. Although many countries with state-church systems do not discriminate against other religious organisations or deny them the rights and privileges enjoyed by state churches, ${ }^{23}$ a ban on establishing a state church can actually open up a space for a wide range of religious symbols to be used in the public sphere, in the broadest sense of the term. Due to objective differences between religious groups, the largest and most traditional religious organisations take up the most space in the public sphere. Thus, the presence of religious symbols in the public sphere does not violate the establishment clause because it does not establish a state religion. The fact that a symbol associated with a particular religion is used in a state or public space does not determine the status of that religion or religious organisation in the legal system. If it did, images of Lady Justice in courtrooms around the world would give the religion of ancient Rome the status of state religion in many countries, which clearly they do not.

\subsection{The protection of freedom of religion}

The constitution of the Republic of Serbia guarantees freedom of thought, conscience, belief, and religion, 'as well as the right to stand by one's belief or religion or change them by choice'. ${ }^{24}$ The constitutional provisions contained in art. 43 of the constitution affirm the principle of individual religious freedom and the protection of collective religious rights. The Law on Churches and Religious Communities elaborates on both of these principles, making them concrete. ${ }^{25}$ This freedom includes the freedom to manifest religion or belief. The constitution expresses this in the following way: 'Everyone shall have the freedom to manifest their religion or religious beliefs in worship, observation, practice, and teaching, individually or in community with others, and to manifest religious beliefs in private or public'. ${ }^{26}$ The constitution of the Republic of Serbia guarantees the right to freely express religious beliefs collectively and individually. It therefore protects the use of religious symbols in private or public, as one way of expressing religious beliefs.

The individual right to freedom of religion is generally exercised within a certain collectivity, associated with a concrete collective identity. The freedom to express religious beliefs makes sense only if it is guaranteed to both individuals and religious

22 Constitution of the Republic of Serbia, art. 11.

23 Avramović, 2007, p. 105.

24 Constitution of the Republic of Serbia, art. 43.

25 Radulović, 2014, p. 25.

26 Constitution of the Republic of Serbia, art. 43. 
communities, giving them the right to express their collective religious identities and beliefs. ${ }^{27}$ For this reason, the constitution guarantees the right to use religious symbols in public to individuals and religious groups (churches and religious communities) equally.

\subsection{The principle of restriction of freedom of religion}

The freedom to express religious beliefs is one element of freedom of religion. Freedom of religion in its external aspect (forum externum) is not an absolute right. However, any restriction of this right must meet the conditions prescribed by the constitution:

Freedom to manifest religion or beliefs may be restricted by law only if it is necessary in a democratic society to protect the lives and health of the people, the morals of a democratic society, the freedoms and rights guaranteed by the constitution, or public safety and order, or to prevent the incitement of religious, national, or racial hatred. ${ }^{28}$

Similar restrictions are included in international human-rights instruments, from which they are derived. ${ }^{29}$ Such restrictions are needed to prevent possible abuse, as religious symbols can be manipulated and instrumentalised by extremist organisations and movements. ${ }^{30}$ Appropriate restrictions can prevent members of such organisations from hiding behind a veil of protection while promoting their organisations and misleading the public. Serbia's restrictions on the freedom of religion are in line with international standards for the protection of human rights and freedoms.

\subsection{The principle of cooperation between the state and churches and religious communities}

The constitution of the Republic of Serbia does not declare explicitly that the state may cooperate with churches and religious communities. However, such cooperation is not explicitly prohibited; the prevailing view is that state-church cooperation is not unconstitutional, as long as it does not violate the principle of state secularity. The laws that regulate the status of churches and religious communities in Serbia, as well as those that regulate rights they exercise in various domains, are based on the principle of state-church cooperation or cooperative separation. ${ }^{31}$ Cooperation between the state and churches and religious communities is realised

27 Avramović and Rakitić, 2009, p. 96.

28 Constitution of the Republic of Serbia, art. 43.

29 European Convention for the Protection of Human Rights and Fundamental Freedoms, art. 9; International Covenant on Civil and Political Rights, art. 18.

30 Prevention of Radicalization and Terrorism, pp. 20-22.

31 Avramović, 2011, p. 299. 
in various spheres and areas. One consequence of this cooperation is the presence of religious symbols in public and state institutions. For example, religion classes taught in public schools entail the use of didactic aids which, as a rule, contain the symbols and signs of religious organisations. Another example is the Law on Public Service Broadcasting, which provides media space to churches and religious communities, ${ }^{32}$ enabling the use of various religious symbols in public media-service programs. Thus, the principle of cooperation between the state and churches and religious communities has indirectly contributed to strengthening the presence of religious symbols in public, in all areas where the state and religious organisations can cooperate.

\subsection{The principle of non-discrimination}

The constitution of the Republic of Serbia prohibits discrimination, in particular discrimination on grounds of religion. ${ }^{33}$ It is worth asking whether the use of certain religious symbols in the public sphere discriminates against all religious organisations that do not identify with those symbols. Generally speaking, all religious communities are equal; in regulating the cooperation between the state and the church, Serbian legislation does not differentiate between different religious organisations. In practice, there are reasonable limits to the freedoms of religious organisations, as the symbols of all existing, registered, and unregistered religious organisations can be present at the same time or to the same extent in the public sphere. Such factual and reasonable restrictions do not represent discrimination, since they do not involve the unequal regulation of similar situations. ${ }^{34}$ In addition, objective differences between religious organisations result in different levels of public interest. It is completely natural for the religious symbols of traditional churches and religious communities, to which most citizens belong, to be more present in the public sphere than those of other religious organisations. Importantly, no regulation legitimises such restrictions, which would make religious affiliation the basis for discriminating against other religious organisations and their members.

\subsection{The principle of equity and equality of churches and religious communities}

The principle that all churches and religious communities are equal is connected to the principle of non-discrimination. The constitution of the Republic of Serbia states twice that churches and religious communities are equal..$^{35}$ As with the principle of discrimination, the question is whether the use of symbols 
associated with certain religious organisations violates the principle of equity and equality of all religious organisations. It would be extremely impractical to display the symbols of all existing religious organisations in the public sphere. In practice, the symbols of traditional churches and religious communities dominate the public sphere, although other religious organisations face no legal obstacle in displaying their own. Importantly, the regulations on cooperation between the state and churches and religious communities do not restrict the use of religious symbols or distinguish between religious organisations. Finally, it is important to emphasise the distinction between equality and identity. As G. Robbers observed: 'To safeguard religious liberty, the correct paradigm is equal rights, not identical rights ... Identical rights would preclude a multitude of manifestations of positive religious freedom'. ${ }^{36}$

\section{Model of relations between the state and the church}

\subsection{General principles}

The literature presents various systems of relations between the state and the church. Their criteria differ, as do the total number of identified models. ${ }^{37}$ For example, R. Hirschl identifies nine archetypical models of church-state relations. ${ }^{38}$ This section presents three systems of relations between the state and the church, known as the classical, conventional, and traditional models in the European literature. ${ }^{39}$ As previously mentioned, this classification has been accepted in the Serbian literature; it significantly influenced the outcome of the debate on the constitutionality of the 2006 Serbian Law on Churches and Religious Communities. In accordance with this classification system, all systems of relations between the state and the church belong to one of the following three models: the model of strict (absolute) separation, the model of the state church, and the model of cooperative separation.

In the state-church system, one or more religious entities has a special constitutional status, is institutionally connected to the state, and enjoys special privileges. These privileges consist mainly of funds from the state budget and tax exemptions. State-church systems are not monolithic. There are significant differences in the degree of autonomy given to the established churches. For example, the Church 2009, pp. 10-12; Sandberg, 2008, pp. 329-352, Džomić, 2012, p. 358. 
of Denmark is institutionally connected to the state, or rather, integrated into the state apparatus. The Church of Denmark does not have its own synod or council. It has no central organs or religious leader and is not a corporate body ${ }^{40}$ The Church of England has a slightly higher degree of self-government, adopting its own measures with its own General Synod. ${ }^{41}$ Although Greece has a state-church system, the Greek Church has wide autonomy. Like other Orthodox churches, it also has its own central administration (a Council and Synod). It has the legal subjectivity of public law and can independently pass regulations to govern church affairs exclusively. ${ }^{42}$ It is important to emphasise that implementing a state-church system does not imply discrimination against religious organisations that lack the same status as the state church. This system in its classical form in Europe is a relic of the past. The number of countries that use it is constantly decreasing. In fact, most countries are modifying these systems and moving toward systems of cooperation, as discussed below.

Another model in the tripartite classification of European state-church relations is the system of strict separation. In systems of strict separation, the state and church are institutionally separated and act independently, each in its own domain. This does not mean that the state is indifferent to the religious needs of its citizens. On the contrary, the state works proactively to guarantee all preconditions for the unimpeded exercise of freedom of religion. Another feature of these systems is state neutrality: a lack of identification with any religious organisation. Writing about systems of strict separation, Russell Sandberg explains the obligation of state neutrality as follows:

Neutrality is not a passive obligation: rather, in its pursuit of religious freedom and equality, the state actively seeks to remove all existing boundaries and often seeks to provide the means whereby all citizens-regardless of their religious convictionsenjoy the equal right to manifest their religiosity throughout their everyday life. ${ }^{43}$

In the vast majority of papers on this topic, France is used as an example of a system of strict separation, likely because this system appeared following the French Revolution. However, as some authors have already pointed out, ${ }^{44}$ the principle of laïcité in France does not present an obstacle to cooperation between the state and religious organisations. This cooperation has developed over time, as the idea of hermetically isolating the state and church has proved unsustainable in practice. There are numerous examples of cooperation, from the maintenance of religious buildings belonging to one group (Roman Catholics) being financed from the budget, and state 
funding of religious education in certain parts of France, to the development of the theoretical concept of laïcité positive, which French President Nicolas Sarkozy defined as 'an open secularism, an invitation to dialogue, tolerance, and respect. It is a new chance, a jump, a further dimension to public debate'. ${ }^{45}$ In practice, strict separation systems are gradually approaching the cooperative separation model; in fact, it can be difficult to identify their differences or the criteria that differentiate the two systems.

\subsection{Cooperation between state and religious communities}

Between the two extremes, i.e. the system of church-state unity and strict separation, a whole range of different models has emerged. In the classical tripartite classification system, these are known as systems of cooperation, hybrid systems, or systems of cooperative separation. ${ }^{46}$ In the Serbian literature, they are defined as systems in which the state and the church are separate but cooperate in matters of common interest and actions that cannot be performed well without cooperation. ${ }^{47}$ The problem with this definition is that it does not include criteria for distinguishing between systems of strict and cooperative separation. It can therefore be applied to most countries with strict separation systems (France, the US, Slovenia). Cooperation between the state and religious organisations exists in both state-church and strict separation systems. ${ }^{48}$ The difficulty is that the tripartite division is based mainly on an analysis of constitutional norms. The real relationship between state and church is far richer than any constitutional description. Due to the obvious convergence of different European systems of state-church relations, it is increasingly difficult to draw a clear line between them. A system of cooperative separation can be defined as a system in which the constitutional principle of church-state separation does not represent an obstacle to cooperation in various domains. In this system, the scope of cooperation is not specified by the constitution (it does not belong to materia constitutionis) and varies, depending on circumstances. Legislatures have a broad remit for determining specific areas in which the state and church will cooperate and how that cooperation will be realised. The state's benevolent attitude towards religious organisations recognises the positive role they play in the development of democratic pluralistic societies. This system of relations between the state and the church is accepted in the vast majority of European countries and can be said to represent the expression of European Christian values in the modern age.

45 Gomes, 2009, pp. 214-215.

46 Đurđević, 2009, p. 125; Marinković, 2011, p. 378; Avramović, 2011, p. 296; Avramović, 2007, p. 107; Sandberg, 2008, pp. 329-352; Gujaničić, 2012, p. 121.

47 Avramović, 2007, p. 107; Robbers, 2005, pp. 578-579.

48 Sandberg, 2008, pp. 329-352. 


\section{Constitutional guarantees of freedom of conscience and religion}

Freedom of conscience and religion is a basic human right, guaranteed by numerous universal and regional human-rights instruments. ${ }^{49}$ The guarantees contained in international documents have been received and incorporated into the constitutions and legislation of most, if not all, European countries. Provisions in the 2006 Constitution of the Republic of Serbia provide the same range of protections of freedom of religion as most international treaties and conventions that regulate that freedom. The framers of the Serbian constitution paid special attention to individual and collective ways of exercising the freedom of religion, while leaving some important issues, such as the possibility of financing churches and religious communities, to the legislature.

Freedom of religion is a specific right with two dimensions: individual and collective. For this reason, it has two subjects: individuals and their communities. Freedom of religion for individuals is regulated by art. 43 of the constitution of the Republic of Serbia, while art. 44 is dedicated to the collective or corporate aspect of that freedom.

In the first category of subjects of religious freedom, it is theoretically possible for someone to possess religious beliefs but not to express them in any way. In its internal form (forum internum), freedom of religion is an absolute right. ${ }^{50}$ In essence, forum internum is beyond the reach of the legislature, because it is theoretically possible to conceal religious beliefs or to simulate an affiliation with a religious organisation (e.g. Crypto-Christianity). In that sense, the forum internum of religious freedom is an absolute right, thanks not only to absolute legal protection, but more importantly to the freedom and elusiveness of the human spirit, which is never subject to any restrictions.

However, religion, the inner relationship between human beings and the transcendent, tends to be manifested in the outer world. It has an innate tendency to move beyond the frame of the inner human sphere (forum internum) to manifest in the outer world in various ways. ${ }^{51}$ When internal religious beliefs are manifested, they enter the world of law and become the subject of legal regulations, like every other legally relevant statement of will (the forum externum of freedom of religion). As freedom to manifest religious beliefs is not an absolute right, it can be restricted, in accordance with the standards prescribed in international documents that protect human rights and freedoms.

49 Universal Declaration of Human Rights, art. 18; European Convention for the Protection of Human Rights and Fundamental Freedoms, art. 9; International Covenant on Civil and Political Rights, art. 18.

50 Marinković, 2011, pp. 368-369; Đurđević, 2009, p. 67.

51 Harris, O’Boyle, Warbick, 2014, p. 428. 
Arts. 43 and 44 of the constitution of the Republic of Serbia regulate both elements of freedom of religion: external and internal. The constitution regulates in more detail certain aspects of freedom of religion in relation to the relevant international documents. The drafters of the constitution had greater freedom because they were regulating a specific legal system, while universal international treaties must be compatible with a range of different legal systems and legal traditions. In addition, the drafters of the constitution had to consider the practice of international courts, which interpret and elaborate the provisions laid out in international conventions and declarations.

In accordance with art. 43, para. 1 of the constitution of the Republic of Serbia 'Freedom of thought, conscience, belief, and religion is guaranteed, as well as the right to adhere to one's belief or religion or to change them according to one's own choice. ${ }^{52}$ In accordance with the tendencies observed in international instruments for the protection of human rights, freedom of religion is guaranteed, alongside freedom of thought, conscience, and belief. ${ }^{53}$ These freedoms, which are absolutely protected, imply the right to have, retain, change, and choose a religion or belief. Such constitutional guarantees protect the individual aspect of freedom of religion from unauthorised state intervention. They also protect people's individual rights in relation to religious organisations, which cannot prevent their followers from freely choosing or changing their religious beliefs. Finally, these provisions protect individuals from the forcible or forced imposition of religious beliefs or the establishment of a mandatory religion, which art. 11 of the constitution of Republic Serbia explicitly prohibits. ${ }^{54}$

Art. 43, para. 2, of the constitution of the Republic of Serbia stipulates that 'No person shall have the obligation to declare his religious or other beliefs'. ${ }^{55}$ The constitution thus regulates the right to manifest no religion or belief, which, in the practice of the European Court of Human Rights, is referred to as a negative aspect of the right to manifest religious beliefs. ${ }^{56}$ It includes the right of every individual to not manifest his or her religion or belief, to not declare them, and to not be forced by legal procedures to even partially reveal his or her religious beliefs or their non-existence. ${ }^{57}$ The literature generally argues that the right to not declare one's religious beliefs belongs to the forum internum of freedom of religion, a category of rights that must not be restricted. ${ }^{58}$ The question is whether the use of religious symbols in the public sphere can violate the negative aspect of protection of freedom of religion. Bearing in mind that there is no obligation to use religious symbols in the public sphere, and that their use depends exclusively on individual free choice, it cannot be

52 Constitution of the Republic of Serbia, art. 43.

53 Charter of Fundamental Rights of the European Union, art. 10.

54 Đurić, 2012, p. 33.

55 Constitution of the Republic of Serbia, art. 43.

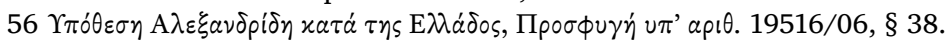

57 Đukić, 2014, pp. 57, 75.

58 Roberts, 2014, pp. 43-47. 
claimed that the use of religious symbols in the public sphere represents a form of coercion or pressure, designed to force individuals to declare their religious beliefs. In addition, the presence of religious symbols in the public sphere does not imply that anyone identifies with the religious organisation that those symbols represent.

The constitution of the Republic of Serbia guarantees the right to manifest religious beliefs: 'Everyone shall have the freedom to manifest their religion or religious beliefs in worship, observation, practice and teaching, individually or in community with others, and to manifest religious beliefs in private or public'. ${ }^{59}$ The constitution, by way of example, specifies a few ways in which religion can be manifested. The last part of the provision generally states that everyone has the right to manifest religious beliefs in private or in public. Religious beliefs can be manifested through the use of religious symbols and in other ways. The constitution guarantees that all individuals can publicly manifest their religious beliefs through the use of religious symbols.

As previously mentioned, the forum externum of freedom of religion is not an absolute right; under certain conditions, it can be limited. After the provision guaranteeing the individual and collective right to manifest religious beliefs, the drafters of the constitution imposed restrictions on that right. According to art. 43, para. 4:

Freedom to manifest religion or beliefs may be restricted by law only if this is necessary in a democratic society to protect the lives and health of people, the morals of the democratic society, freedoms and rights guaranteed by the constitution, and public safety and order, or to prevent inciting of religious, national, and racial hatred. ${ }^{60}$

This provision does not differ much, either from the regulations of the European Convention for the Protection of Human Rights and Fundamental Freedoms, which restricts the right to freedom of expression or belief, or from the restrictions of other rights guaranteed by that convention. ${ }^{61}$ In relation to the European Convention, the constitution specifies several legitimate aims that can justify the restriction of religious freedoms; however, it does not depart from the solutions contained in other international treaties, such as the International Covenant on Civil and Political Rights. $^{62}$

In addition to the individual aspect of freedom of religion, the constitution of the Republic of Serbia also regulates its corporate aspect. The constitution first guarantees the equality of all religious organisations, twice mentioning the separation between the state and churches and religious communities (in arts. 11 and 44) It describes the protection of religious autonomy in detail: 'Churches and religious

59 Constitution of the Republic of Serbia, art. 43.

60 Constitution of the Republic of Serbia, art. 43.

61 Convention for the Protection of Human Rights and Fundamental Freedoms, art. 9.

62 International Covenant on Civil and Political Rights, art. 18. 
communities shall be equal and free to organise independently their internal structure, religious matters, to perform religious rites in public, and to establish and manage religious schools and social and charity institutions, in accordance with the law'. ${ }^{63}$ It is important to note that the constitution of the Republic of Serbia guarantees the right to perform religious rites publicly to all subjects, both individuals and religious organisations. Since the performance of religious rites generally implies the use of certain symbols, the constitution also guarantees the right to use such symbols in public. In accordance with the provisions of the constitution, this right is limited only in the case of religious rites conducted by religious organisations. Individuals can use religious symbols to manifest their religion both privately and publicly without restriction.

According to the constitution, the Constitutional Court has the right to ban a religious community under certain conditions:

'The Constitutional Court may ban a religious community only if its activities infringe on the right to life, the right to mental and physical health, the rights of the child, family integrity, or public safety and order-or if they incite religious, national, or racial intolerance. ${ }^{64}$

This provision contains an interesting terminological inconsistency. Unlike the rest of the constitutional text and the other regulations that govern religious freedom, this provision mentions religious communities only-not churches.

For some authors, this omission suggests that the constitution intentionally provides for the possibility of banning only religious organisations not identified as churches. ${ }^{65}$ The Law on the Constitutional Court, which regulates the prohibition procedure supports that position. ${ }^{66}$ At the same time, the constitution states that churches and religious communities are equal; such an interpretation would mean that the drafters of the constitution were inconsistent and created an inequality and inequity between churches and religious communities. This contradiction suggests that the omission was unintentional, as Ministry of Religion representatives have pointed out. ${ }^{67}$ The issue has more theoretical than practical significance because the Constitutional Court has never banned any church or religious community.

Since banning a religious organisation restricts its right to freedom of religion, art. 20 of the constitution of the Republic of Serbia provides the following clarification:

When restricting human and minority rights, all state bodies, particularly the courts, shall be obliged to consider the substance of the restricted right, the pertinence of the 
restriction, the nature and extent of the restriction, the relation of the restriction, its purpose, and the possibility of achieving that purpose with less restrictive means. ${ }^{68}$

Also, in accordance with art. 202, the derogation of human rights is allowed in a state of emergency or war, as long as no measures are allowed to interfere with certain rights, including freedom of religion. ${ }^{69}$

To ensure the effective judicial protection of human rights, the constitution stipulates that a constitutional complaint may be lodged against individual acts or the actions of state bodies or organisations entrusted with public authority and denied human rights and freedoms, ${ }^{70}$ if the legal remedies for their protection are exhausted or not provided. All persons who are subjects of the human rights guaranteed by the constitution have active legitimation. In accordance with the law, the Constitutional Court may 'annul an individual act, ban further performance of an action, or order another measure or action to eliminate the harmful consequences of an established violation or denial of guaranteed rights and freedoms and determine the manner of just satisfaction of the applicant'. ${ }^{71}$ The constitutional complaint has proven to be an effective way of resolving disputes over human-rights restrictions. The Constitutional Court case law on restrictions of the right to freedom of religion is based entirely on constitutional appeals.

\section{Guarantees provided by other sources of universally binding law}

The cardinal law that regulates the freedom of religion in the Republic of Serbia is the 2006 Law on Churches and Religious Communities. This law comprehensively regulates the legal position of churches and religious communities. Although it was passed a few months before the current constitution, its provisions on the freedom to manifest religious beliefs do not differ fundamentally from the constitutional provisions. According to art. 1 of the law, freedom of religion includes, among other things, the

freedom to manifest belief or religious conviction either individually or in community with others, in public or in private, by participating in religious services and performing religious ceremonies, through religious teachings and instructions, cherishing and developing religious tradition. ${ }^{72}$ 
Importantly, the manifestation of freedom of religion extends to nurturing and developing religious traditions.

Religious officials often wear special insignia or vestments. In accordance with art. 8 of the Law on Churches and Religious Communities, the vestments of religious officials have official uniform status. This law obliges the state to protect the official uniforms of all religious officials, as well as all aspects of their insignia of rank and dignity. The protection is exercised 'in accordance with the law and the autonomous right of a church or religious community'. ${ }^{73}$ All religious symbols are subjects of state protection; they are also an integral part of the vestments of priests and religious officials.

The Constitutional Court debate on the constitutionality of the Law on Churches and Religious Communities articulated the state's obligation to protect only its own symbols, implying that the law cannot establish the state's obligation to protect the official uniforms of priests and religious officials. ${ }^{74}$ In response, the National Assembly pointed out that the state not only protects its symbols, but must also protect 'religious symbols and signs'. ${ }^{75}$ The Constitutional Court argued that the official uniforms of religious people were a way of expressing freedom of religion, implying that the state is obliged to 'protect the wearing of an official uniform and its parts, as a sign of rank and dignity of clergy, that is, of religious officials'. ${ }^{76}$

The Law on Churches and Religious Communities regulates the worship-related activities of all religious organisations. Such activities may be carried out in public places 'as well as in the places related to significant historical events or persons, in accordance with the law'. ${ }^{77}$ The places and times associated with religious ceremonies also enjoy protection. Since most religious rites are performed with the use of religious symbols, religious freedom cannot be protected without also protecting the use of religious symbols in the public sphere.

Importantly, the legislature guarantees that religious rites 'may also be performed in hospitals, military and police facilities, institutions for executing criminal sanctions, and other institutions and facilities, upon request of the competent body, while in schools and social and child-care institutions, religious service and ceremonies may be performed only on appropriate occasions'.$^{78}$ One assessment of the constitutionality of this law claimed that performing religious rites in public places or state institutions would turn a public space into a place of worship, placing state institutions under the illegal influence of religious organisations. ${ }^{79}$ According to the

73 Law on Churches and Religious Communities, art. 8.

74 IUz- 455/2011.

75 Otvorena pitanja postupka ocene ustavnosti Zakona o crkvama i verskim zajednicama, p. 160.

76 IUz- 455/2011.

77 Law on Churches and Religious Communities, art. 31.

78 Law on Churches and Religious Communities, art. 31.

79 IUz- 455/2011. 
Constitutional Court, the performance of religious rites in public spaces or state institutions does not violate their secular character. The right to practice religion freely in public is guaranteed by the constitution and can be restricted only under precise, predetermined conditions. ${ }^{80}$ Religious rites are regulated in ways that do not affect the work of state institutions and or make their activities in any way religious. Instead, they remain religiously neutral, ensuring that the principle of church-state separation is not violated.

The presence of religious symbols in state institutions in Serbia goes beyond the framework needed for worship. Since the introduction of confessional religious education in the Serbian school system, ${ }^{81}$ religious symbols have been used both as teaching tools and to decorate the school premises they were removed from decades earlier. Religious education is offered in all primary and secondary school grades. ${ }^{82}$ It is an elective, confessional subject, which can be only be taught at state expense by traditional churches and religious communities. ${ }^{83}$

In the Serbian Armed Forces, chaplaincy service is regulated by the 2011 Decree of the Government of the Republic of Serbia.$^{84}$ In accordance with that decree, chaplains who perform religious services for the Serbian Armed Forces have the right to wear religious clothes but only while performing religious activities. Their uniforms can also include religious symbols. Military priests perform liturgical services and religious rites. They also organise lectures and pilgrimages, cooperate with other services, carry out pastoral-advisory work, and equip liturgical areas with movable objects and literature. Military priests can also perform religious rites outside religious premises, with the consent of military elders and religious dignitaries. Thanks to religious officers in the Serbian Armed Forces, the number of religious symbols in military facilities has increased.

Preventing or restricting the freedom to express religious beliefs or perform religious rites is sanctioned by the Criminal Code. ${ }^{85}$ Any restriction of religious freedom is punishable by a fine or imprisonment of up to one year. In addition, preventing or obstructing religious rites incurs the same penalty. An official who commits a qualified form of this crime can receive a prison sentence of up to three years. Freedom of religion means the freedom to express religious beliefs (forum externum). ${ }^{86}$ Although this provision of the Criminal Code is not sufficiently precise, when religious organisations use religious symbols to express their beliefs in public or private, they also enjoy criminal justice protection.

$80 \mathrm{IUz}-455 / 2011$.

81 Decree on the organisation and realisation of religious education and the teaching of alternative subjects in primary and secondary schools.

82 Law on the fundamentals of the education system, art. 60.

83 Avramović, 2016, pp. 39-46.

84 Decree on the performance of religious services in the Serbian Army.

85 Criminal Code, art. 131.

86 Vuković, 2016, p. 101. 
The Identity Card law stipulates that a person who wears a hat or a scarf for religious reasons may be photographed with that garment to provide biometric data. ${ }^{87}$ The laws on travel documents ${ }^{88}$ and driver's licenses ${ }^{89}$ do not include similar regulations in relation to biometric data. ${ }^{90}$ In practice, there has never been a problem with the issuance of biometric personal documents, due to the wearing of religious symbols.

According to the Law on Public Media Services, the respect and encouragement of religious pluralism is a public interest. ${ }^{91}$ The main activity of public media 'includes the production, purchase, processing and publishing of radio, television and multimedia content, especially informative, educational, cultural and artistic, children's, entertaining, sports, religious, and other categories of public interest to citizens'. ${ }^{92}$ The Law on Electronic Media stipulates that churches and religious communities can act as media-service providers to satisfy the interests of certain social groups. ${ }^{93}$ The content of these programs must relate to the activities of churches and religious communities; permits are issued for local and regional coverage only. This means that church and religious media, which the legislature classifies as civil-sector electronic media, cannot receive national coverage. These laws enable churches and religious communities to edit their own media and spread their ideas, attitudes, and doctrines through electronic media, increasing their participation in the public sphere.

For the most part, Serbian legislation indirectly and affirmatively regulates the presence of religious symbols in the public sphere. Although religious symbols are not explicitly mentioned, both the freedom to manifest religious beliefs and the right to disseminate religious ideas are protected by various regulations, which also cover the use of religious symbols in the public sphere.

\section{Limitations on religious expression through the use of religious symbols}

The freedom to manifest religious beliefs is not an absolute right, as it is subject to certain restrictions. The conditions under which the freedom of religion can be restricted are prescribed by the constitution of the Republic of Serbia and the Law on Churches and Religious Communities. However, the presence of religious symbols in public is not regulated by special regulations. According to the norms that regulate

87 Identity Card Law, art. 10.

88 Law on Travel Documents.

89 Rules on driving licenses.

90 Rules on Travel Documents.

91 Law on Public Service Broadcasting, art. 7.

92 Law on Public Service Broadcasting, art. 3.

93 Law on Electronic Media, art. 72. 
the expression of freedom of religion, state regulations permit the use of religious symbols within the framework of freedom of religious expression.

The Republic of Serbia has no special regulations restricting the use of religious symbols, unlike some Western countries, which prohibit the wearing of religious symbols in public institutions. Although no normative solutions limit the use of religious symbols, scholars have argued that religious symbols in the public sphere desecularise society and the state. ${ }^{94}$ However, none of the cases analysed in these papers has had a judicial epilogue or led to judicial interventions.

In the Code of Conduct for Civil Servants, passed by the High Council of Civil Servants, ${ }^{95}$ a civil servant cannot express a religious affiliation through his or her dress, as this could 'call into question his impartiality and neutrality'. Only those religious symbols that could call into question the impartiality and neutrality of a public servant are banned. They include symbols of extremist organisations that abuse religious symbols for their own purposes.

The special regulations that govern the arrangement, equipping, and appearance of public offices belonging to notaries, executives, and attorneys do not limit the use of religious symbols in these offices. People working in public offices often display various religious symbols. Individuals generally arrange their own workspaces to express their own personal religious beliefs. These practices have not resulted in any litigation to date.

The use of religious symbols is not legally restricted in Serbian public schools. Based on the Law on the Fundamentals of the Education System, school councils may lay down rules of conduct, including dress codes for students and teachers. ${ }^{96}$ Although it is not possible to analyse the rulebooks of every school, most prohibit discrimination based on religious affiliation; some ban clothing that promotes a religious affiliation. In addition, parents may be prohibited from expressing their religious or personal affiliations through their clothes. ${ }^{97}$ However, most schools do not ask students or parents not to wear religious symbols.

Religious symbols are often present in kindergartens and schools, with no regulations to control their presence. ${ }^{98}$ Occasionally, some NGOs or individuals speak out against this practice, referring to the separation of church and state. ${ }^{99}$ However, this practice is not institutionalised. It simply reflects the fact that schools celebrate the feasts of their patron saints. As parents themselves donate icons and other religious symbols, this does not violate the principle of church-state separation. The presence of religious symbols does not affect teaching, learning, or school administration. The religious symbols are chosen by independent school bodies, not religious

94 Simović and Simeunović-Patić, 2016, p. 112.

95 Code of Conduct for Civil Servants, art. 17.

96 Law on the fundamentals of the education system, art. 119.

97 Rules of conduct and dress code.

98 Approach in the UK: Bacquet, 2009, pp. 123-125; in Europe: Ringelheim, 2012, pp. 283-304.

99 See: https://www.021.rs/story/Novi-Sad/Vesti/115592/Da-li-je-ikonama-mesto-u-vrticima-i-skolamau-Novom-Sadu.html. 
organisations. Nonetheless, this issue is not legally regulated by the Republic of Serbia.

According to the statutes of the University of Belgrade, religious feast days may be celebrated, ${ }^{100}$ but all other religious activities and organisations are prohibited. Religious holiday celebrations tend to involve religious symbols. In many university premises, such symbols are present only during religious holidays. We should remember that many religious symbols also have secular significance, while many church figures have made a huge contribution to the development of science and literacy.

Hospitals have their own house rules, which determine the treatment of healthcare users and employee rules of conduct. Some hospitals allow priests to visit patients to perform religious rites. ${ }^{101}$ Many hospitals have chapels, where believers can fulfil their religious needs. Over the last few years, there has been a noticeable tendency to build new hospital chapels. This means that healthcare users in all Serbian hospitals will soon be able to exercise the rights guaranteed by the Law on Churches and Religious Communities, which explicitly stipulates that liturgical and religious rites can be performed in hospitals at the request of the competent authority. ${ }^{102}$

When it comes to companies, the law does not restrict the use of religious symbols or words in business names or logos. The Law on Companies simply states that a company's name must not offend public morals. ${ }^{103}$ The Law on Trademarks gives companies the right to have trademarks and logos, as long as they are not 'contrary to the public order or accepted moral principles'. ${ }^{104}$ According to the Intellectual Property Office Methodology of Conduct, all signs that insult religious beliefs are treated as immoral in trademark recognition proceedings and proceedings under registered trademarks. In addition, a trademark cannot be granted for a mark that represents or imitates a religious symbol. ${ }^{105}$ The same act specifies that signs can be expressed in words and/or graphics; it gives examples of names and figures of saints used inappropriately. In this way, the legislature protects religious symbols from possible corporate abuse. It also protects the dignity of religious organisations and their followers.

The use of religious symbols on the Internet and social networks is not sufficiently regulated by law. Religious symbols, including the official symbols of religious organisations, are often abused online. ${ }^{106}$ Given the development of social networks and their importance during the current pandemic, this area is likely to be managed through special regulations.

100 Statute of the University of Belgrade, art. 8.

101 See: http://bolnica.org.rs/wp-content/uploads/2019/03/Kucni-red.pdf.

102 Law on Churches and Religious Communities, art. 31.

103 Law on Companies, art. 27.

104 Law on Trademarks, art. 5.

105 Methodology of Conduct of the Intellectual Property Office, pp. 54-55, 70.

106 See: www.spc.rs/sr/zloupotreba_zvanichnih_naziva_eparhije_vranjske_manastira_na_drushtvenim_ mrezhama. 


\section{The system of legal protection}

Courts in the Republic of Serbia rarely deal with cases involving the protection of religious freedom. ${ }^{107}$ The legal framework that governs the exercise of individual and collective religious freedoms enables the unconstrained manifestation of religious beliefs in both the public and private domains. The lack of restrictive laws limiting the use of religious symbols leaves room for their use in the public sphere. This relaxed approach has been optimal because it does not cause inter-religious or interethnic tensions; instead, it gives each individual enough space to decide independently whether or how to manifest religious beliefs through various religious symbols.

In case law, disputes over trademarks and intellectual property have focused on religious symbols. One of the first lawsuits about religious symbols was a dispute over the use of the name and image of Saint Sava from a fresco in the medieval Orthodox Mileševa Monastery. The defendants sold bottles of wine labelled 'Sanctity' with an image of Saint Sava. The court ruled that the defendants had committed an act of unfair competition and violated the trademark protected by the Serbian Orthodox Church. ${ }^{108}$ Although a similar dispute arose over the unauthorised use of an image of the White Angel from the same Orthodox monastery, it did not lead to a verdict. ${ }^{109}$

In the Republic of Serbia, religious symbols enjoy criminal justice protection. One of the few regulations that explicitly mentions religious symbols is the Criminal Code. The criminal offense of inciting national, racial, or religious hatred and intolerance carries a prison sentence of six months to five years. One version of this crime is denigrating religious symbols; this carries a prison sentence of one to eight years. Only secular uses of religious subjects that provoke or incite religious hatred are forbidden; ${ }^{110}$ other secular uses are not forbidden. During the 2019 Belgrade Pride, one participant marched in the parade with an icon of the Virgin Mary with her halo painted in rainbow colours. A few citizens and the head of the police union filed lawsuits against him for initiating and provoking religious hatred. The court has still not decided those cases. ${ }^{111}$

Based on a constitutional complaint, filed by the Islamic Community of Serbia, the Constitutional Court ruled on an alleged violation of the freedom of thought, conscience, and religion. ${ }^{112}$ A constitutional appeal was filed against the Supreme Court of Cassation judgment, rejecting a request to review the Administrative Court judgment. The judgment rejected a lawsuit, which claimed that the Ministry of Religion and Diaspora was silent on this subject. In 2006, the subject who submitted

107 Approach in the US: Gunn, 2010, pp. 291-294.

108 Pž. 6501/2004/1.

109 Pž. 7528/2009.

110 Vuković, 2016, p. 106.

111 See: https://www.bbc.com/serbian/lat/srbija-49745940.

112 Už-303/2017. 
the constitutional complaint to the Ministry of Religion applied for inclusion in the Register of Churches and Religious Communities. In accordance with the Law on Churches and Religious Communities, the Islamic community is one of seven traditional churches and religious communities that recognise legal subjectivity ex officio. ${ }^{113}$ Due to divisions within the Islamic community and the simultaneous operation of two non-recognised Islamic communities, the authorities did not register either. Both are treated as traditional religious communities, but without entries in the register. The Constitutional Court analysed case law from the European Court of Human Rights, examining the activities of states facing divisions within once united religious communities. In its decision, the Court found that the restrictions to which the appellant was exposed

could be considered proportionate to the permissible objectives of restricting religious freedom and necessary in a democratic society, given that this was not an obstacle to gaining and enjoying traditional religious community status and that this enabled the peaceful coexistence of both Islamic communities in the same status. ${ }^{114}$

Thus, the legal protection of freedom of religion in the Republic of Serbia takes into account European Court of Human Rights practice, using the same methodology to identify freedom-of-religion violations.

\section{Conclusions}

The use of religious symbols in the public sphere is not regulated exhaustively by Serbian laws. The legal guidelines associated with the Law on Churches and Religious Communities regulate the right to manifest religious affiliations, as well as the liturgical activities of churches and religious communities. In practice, religious symbols are often present in the public sphere, mainly due to informal initiatives and the individual expression of religious beliefs. Although there have been attempts to limit the use of religious symbols in public, they have not received court judgments. In addition, the legislature has never intervened by amending the existing legislation.

Various situations related to the presence of religious symbols in the public sphere generate ardent controversies. The first is the presence in public of symbols that most citizens perceive to be exclusively religious, including icons, crucifixes, and statues of saints. These symbols are often present in the public sphere because they have wider historical, identity-related, and cultural significance, as well as 
religious meaning. Although such symbols are not mandatory in the public sphere, they should not be unregulated or left to potential abuses.

The law should clarify the conditions under which symbols with a religious dimension can be used in public, which bodies make the decision, and how their decisions are implemented. This is especially important for public offices, educational institutions, hospitals, and companies. The law should identify the conditions under which the use of such symbols should be restricted and which limits competent authorities must respect. The legislature must protect the use of religious symbols in public spaces, especially given the frequent misconception that their presence violates the constitutional principles of state secularity and church-state separation.

The second situation involves the use of religious symbols in public spaces, such as courts, educational institutions, and state offices. In the Republic of Serbia, there have been no disputes about religious symbols or clothes that reveal someone's religious beliefs. This area should also be regulated, as certain religious practices may conflict with the relevant laws. In some European countries, certain modes of dress are forbidden, even though they manifest faith or belief. In Serbia, the legislature should apply a balanced approach, restricting costumes and symbols, in line with the practices of European countries and the European Court of Human Rights. At the same time, it should leave room for the expression of religious beliefs, using symbols that do not disrupt the harmonious lives of Serbian citizens.

The third controversy involves the practice of constructing religious symbols and monuments in public spaces financed by the government, local authorities, or state-owned companies. In recent years, various religious symbols have been built in public areas. Most have been crosses, chapels, and public fountains with religious ornaments. In academic discourse, such practices are seen as desecularising the public space. However, such facilities do not have merely religious purposes. They express the culture and identity of the vast majority of citizens of the Republic of Serbia. The law should regulate the construction of such facilities, considering both the neutrality of the state and the equality of all religious organisations. At the same time, when drafting urban plans, one should take into account not only the Law on Churches and Religious Communities, but also religious symbols and their visibility in relation to other buildings. For this reason, the law should include religious symbols, as well as religious buildings.

Lastly and most importantly, there is the question of whether manifestations of religion or belief in the public sphere are constitutional-or more precisely, whether religious services and ceremonies that use religious symbols in public or state institutions violate the principle of state secularity. The Constitutional Court has argued that liturgical services carried out in public facilities meet the needs of individuals who use their services without violating the principle of church-state separation. Noticeably, however, many public institutions do not provide the religious rites requested by service users. Although they can refer directly to the Law on Churches and Religious Communities, public institutions should ensure that service users are familiar with their rights and how they should be used. 
No regulations in the Republic of Serbia explicitly prohibit the use of religious symbols. Unlike some European countries, Serbia does not restrict the right to wear religious clothes or insignia. Since prohibitions in European countries relate mainly to non-Christian religious minorities, autochthonous religious pluralism is one reason for this difference. The churches and religious communities that most Serbian believers belong to have existed for centuries and generally share a similar culture and social values.

This situation could change if more migrants settle in the Republic of Serbia. Most pass through on their way to the European Union. If a significant number stay in the Republic of Serbia, however, religious symbols must be regulated within the state's margin of appreciation to achieve a legitimate aim, preserving 'the conditions of "living together" as an element of the "protection of the rights and freedoms of others'.115

Although there have been no legal debates on religious symbols in the public sphere, such debates are a part of the academic and public discourse. For the first time, this paper deals in a comprehensive and interdisciplinary way with the use of religious symbols in the public sphere in the Republic of Serbia, making a significant contribution to that public and academic debate.

115 Case of S.A.S. v. France, Application no. 43835/11, para. 153. Howard, 2020, p. 87; Marinković, 2018, p. 86. 


\section{Bibliography}

AHDAR, R., LEIGH, I. (2013) Religious Freedom in the Liberal State. Oxford: Oxford University Press.

AVRAMOVIĆ S. (2011) 'Poimanje sekularnosti u Srbiji - refleksije sa javne rasprave u Ustavnom sudu' (Understanding Secularity in Serbia - Reflections on Public Hearing in the Constitutional Court), Annals of the Faculty of Law in Belgrade (Belgrade Law Review), 2011/2, pp. 279-301.

AVRAMOVIĆ, S. (2007) Prilozi nastanku srpskog državno-crkvenog prava (State-Church Law in Serbia). Beograd: Službeni glasnik.

Avramović, S. (2016) 'Religious Education in Public Schools and Religious Identity in PostCommunist Serbia', Annals FLB - Belgrade Law Review, 64(3), pp. 25-56.

AVRAMOviĆ, S., RAKITIĆ D. (2009) 'Kolektivna prava i verska sloboda u Srbiji-Istorijskopravno utemeljenje kolektivnih prava tradicionalnih crkava i verskih zajednica u Srbiji' (Collective Rights and Religious Freedom in Serbia - The Historical and Legal Foundation of Collective Rights of Traditional Churches and Religious Communities in Serbia), in Jovanović, M. (ed.) Kolektivna prava i pozitivna diskriminacija u ustavnopravnom sistemu Republike Srbije (Collective Rights and Positive Discrimination in the Constitutional System of the Republic of Serbia). Beograd: Pravni fakultet Univerziteta u Beogradu, Službeni glasnik.

BACQUET, S. (2009) 'Manifestation of Belief and Religious Symbols at Schools: Setting Boundaries in English Courts', Religion and Human Rights, 2009/4, pp. 121-135.

CALO, Z. R. (2012) 'Higher Law Secularism: Religious Symbols, Contested Secularisms, and the Limits of the Establishment Clause', Chicago-Kent Law Review, 87(3), pp. 811-831.

ĐuKIĆ D. (2014) 'Negativni aspekt slobode veroispovesti u praksi Evropskog suda za ljudska prava (Negative Aspect of Freedom of Religion in the Jurisprudence of the European Court of Human Rights)', Harmonius Journal of Legal and Social Studies in South East Europe, 2014/1, pp. 56-77.

ĐukIĆ, D. (2011) Državno-crkveno pravo i grčka pravna tradicija (State-Church Law and Greek Legal Tradition). Beograd: unpublished.

ĐURĐEVIĆ, N. (2009) Ostvarivanje slobode veroispovesti i pravni položaj crkava i verskih zajednica $u$ Republici Srbiji (Exercising Freedom of Religion and the Legal Status of Churches and Religious Communities in the Republic of Serbia). Beograd: Zaštitnik građana.

ĐURIĆ, V. (2012) Sloboda veroispovesti u jurisprudenciji evropskih ustavnih sudova (Freedom of Religion in the Jurisprudence of European Constitutional Courts). Beograd: Institut za uporedno pravo.

ĐURIĆ, V. (2014) Pravni aspekti prikupljanja, upotrebe i značaja statističkih podataka o nacionalnoj, jezičkoj i verskoj pripadnosti stanovništva (Legal Aspects of Collection, Use and Importance of Statistical Data on Ethnicity, Mother Tongue and Religious Affiliation). Beograd: Republički zavod za statistiku, Institut za uporedno pravo.

Džomić, V. (2012) 'Ustavno-pravni sistemi odnosa države sa crkvama i verskim zajednicama u modernoj državnosti (Constitutional and Legal Systems of Relationships Between a State and its Churches and Religious Communities in the Context of Modern Statehood)', Church Studies, 2012/9, pp. 357-383.

Emerson, G. (2018) 'Public Spaces and Religion: An Idea to Debate, A Monument to Analyze', Horizontes Antropológicos, 24 (52), pp. 279-309. 
ETINSKI, R., ĐAJIĆ, S. (2012) Međunarodno javno pravo (International Public Law). Novi Sad: Pravni fakultet.

FERRARI, S. (1995) 'The Emerging Pattern of Church and State in Western Europe: The Italian Model', Brigham Young University Law Review, 1995/2, pp. 421-437.

Gomes, E. X. (2009) 'Church-State Relations from a Catholic Perspective: General Considerations on Nicolas Sarkozy's New Concept of Laïcité Positive', Journal of Catholic Legal Studies, 48(2), pp. 201-218.

GuJANičIć, D. (2012) 'Načelo svetovnosti države u Srbiji (The Principle of Secularity in Serbia)', Politička revija, 34(4), pp. 105-126.

GunN, J. T. (2010) 'Religious Symbols and Religious Expression in the Public Square' in Davis, D. (ed.) The Oxford Handbook of Church and State in the United States. Oxford: Oxford University Press.

HABERMAS, J. (1991) The Structural Transformation of the Public Sphere. Cambridge, MA: The MIT Press.

HALMAI, G. (2017) 'Varieties of State-Church Relations and Religious Freedom through three Case Studies', Michigan State Law Review, 2017(2), pp. 175-207.

HARRIS, D., O'BOYLE M., WARBICK C. (2014) Law of the European Convention on Human Rights. Oxford, UK: Oxford University Press.

HIRSCHL, R. (2010) Constitutional Theocracy. Cambridge, MA/London: Harvard University Press.

HOWARD, E. (2012) Law and the Wearing of Religious Symbols. European Bans on the Wearing of Religious Symbols in Education. London/New York: Routledge. New Edition: Howard, E. (2021) Law and the wearing of Religious Symbols in Europe. London: Routledge.

HowARD, E. (2020) 'Freedom of Religion and the Wearing of Religious Symbols', in Portaru, A. (ed.) A 'Precious Asset'? Vienna: Kairos Publications.

MARINKOviĆ, T. (2011) 'Prilog za javnu raspravu o ustavnosti Zakona o crkvama i verskim zajednicama' (Contribution to the Public Debate on the Constitutionality of the Act on Churches and Religious Communities of the Republic of Serbia), Annals of the Faculty of Law in Belgrade (Belgrade Law Review), 2011/1, pp. 367-385.

MARINKović, T. (2018) 'Religion in Public Spaces-Controversies in the European Court of Human Rights' Case Law' in Brunkhorst, H., Vujadinović, D., Marinković, T. (eds.) European Democracy in Crisis: Polities Under Challenge and Social Movements. Hague: Eleven International Publishing.

MONSMA, S., SOPER, J. (2009) The Challenge of Pluralism-Church and State in Five Democracies. Lanham: Rowman \& Littlefield Publishers.

NAUMOVIĆ, S. (1995) 'Srpsko selo i seljak: između nacionalnog i stranačkog simbola' (Serbian Village and Peasantry Between National and Party Symbols), Glasnik Etnografskog instituta SANU, 1995/XLIV, pp. 114-127.

PUKENIS, R. (2014) 'The Models of Church and State Relations in a Secularised Society of European Union', Asian Journal of Humanities and Social Studies, 2(3), pp. 496-505.

RADUlOVIĆ, M. (2014) Obnova srpskog državno-crkvenog prava (Renewal of Serbian StateChurch Law). Beograd: Konrad Adenauer Stiftung.

RINGELHEIM, J. (2012) 'Rights, Religion and the Public Sphere: The European Court of Human Rights in Search of a Theory?' in Ungureanu C., Zucca L. (eds.) A European Dilemma: Religion and the Public Sphere, Cambridge: Cambridge University Press.

RobBERS, G. (2001) 'Religious Freedom in Germany', Brigham Young University Law Review, 2001/2, pp. 643-668. 
RobBers, G. (2005) State and Church in the European Union. Baden-Baden: Nomos. New Edition: Robbers, G. (2019) State and Church in the European Union. Baden-Baden: Nomos. RoBerts, C. (2014) The Other Side of the Coin? A Critical Examination of the Right Not to Manifest Religion or Belief in art. 9 of the European Convention on Human Rights [Online]. Available at: https://pure.aber.ac.uk/portal/files/27525081/Roberts_Caroline.pdf (Accessed: 27 April 2021).

SANDBERG, R. (2008) 'Church-State Relations in Europe: From Legal Models to an Interdisciplinary Approach', Journal of Religion in Europe, 1(3), pp. 329-352.

SANDBERG, R., DOE, N. (2007) Church - State Relations in Europe [Online]. Available at: https://bit.ly/3CLf7Eb (Accessed: 27 April 2021).

Simović, D., SimEunović-PATIĆ B. (2016) 'Normative Sacred versus Real Desecularisation Road to (in)tolerant and (un)violent Serbian Society', in Jevtić, M., Veković, M. (eds.) 10 Years of the Politics and Religion Journal. Belgrade: Centar za proučavanje religije i versku toleraciju, Univerzitet u Beogradu - Fakultet političkih nauka.

Toron, J., Durham, C. (2015) 'Religion and the Secular State' in Donlu, D. T. (ed.) Religion and the Secular State: National Reports. Madrid: Servicio de Publicaciones Facultad de Derecho Universidad Complutense de Madrid.

VUKOVIĆ, I. (2016) 'O unapređenju krivičnopravne zaštite slobode veroispovesti u srpskom i crnogorskom pravu (On Improving the Criminal Protection of the Freedom of Religion in Serbian and Montenegrin law)', in Ćirić, J., Džomić V., Jevtić M., (eds.) Religija, Politika, Pravo (Religion, Politics, Law). Beograd-Budva: Institut za uporedno pravo, Pravoslavna Mitropolija Crnogorsko-primorska, Centar za proučavanje religije i versku toleranciju.

\section{Legal sources}

Case of S.A.S. v. France, Application no. 43835/11.

Code of Conduct for Civil Servants, Official Gazette of the Republic of Serbia, nos. 29/2008, 30/2015, 20/2018, 42/2018, 80/2019, 32/2020.

Constitution of the Republic of Serbia, Official Gazette of the Republic of Serbia, no. 98/2006, http://www.spc.rs/sr/proslava_sretenja_u_ustanichkom_orashcu

Criminal Code, Official Gazette of the Republic of Serbia, nos. 85/2005, 88/2005, 107/2005, 72/2009, 111/2009, 121/2012, 104/2013, 108/2014, 94/2016, 35/2019.

Decree on the organisation and realisation of religious education and the teaching of alternative subjects in primary and secondary schools, Official Gazette of the Republic of Serbia, no. 46/2001.

Decree on the performance of religious services in the Serbian Army, Official Gazette of the Republic of Serbia, no. 22/2011.

Identity Card Law, Official Gazette of the Republic of Serbia, nos. 62/2006, 36/2011. Identity Card Law, Official Gazette of the Republic of Serbia, nos. 62/2006, 36/2011.

IUz- 455/2011, Official Gazette of the Republic of Serbia, no. 23/2013.

Law on Churches and Religious Communities, Official Gazette of the Republic of Serbia, no. $36 / 2006$.

Law on the Constitutional Court, Official Gazette of the Republic of Serbia, nos. 109/2007, 99/2011, 18/2013, 103/2015, 40/2015.

Law on Electronic Media, Official Gazette of the Republic of Serbia, nos. 83/2014, 6/2016. 
Law on the fundamentals of the education system, Official Gazette of the Republic of Serbia, nos. 88/2017, 27/2018, 27/2018, 10/2019, 6/2020.

Law on Public Service Broadcasting, Official Gazette of the Republic of Serbia, nos. 83/2014, 103/2015, 108/2016, 161/2020.

Law on the Restitution of Property to Churches and Religious Communities, Official Gazette of the Republic of Serbia, no. 46/2006.

Law on Travel Documents, Official Gazette of the Republic of Serbia, nos. 90/2007, 116/2008, 104/2009, 76/2010, 62/2014, 81/2019.

The Methodology Applied by the Intellectual Property Office to the Procedure Relating to the Registration of Trade Marks and the Procedures Based on Registered Trade Marks, https://www.zis.gov.rs/upload/documents/pdf_en/pdf_zigovi/methodology.pdf

Otvorena pitanja postupka ocene ustavnosti Zakona o crkvama i verskim zajednicama (Open issues of the proceedings for an assessment of the constitutionality of the Law on Churches and Religious Communities), in Raković, A., Đurić, V. (eds.) Pravo, vera, kultura (Law, Religion, Culture). Belgrade 2012.

Prevention of radicalization and terrorism (Prevencija radikalizacije $i$ terorizma) [Online]. Available at: https://www.osce.org/files/f/documents/d/b/447076.pdf (Accessed: 27 April 2021).

The Programme of the League of Yugoslav Communists. (1980) Belgrade: Komunist.

Law on the Repeal of Certain Laws and Other Regulations, Official Gazette of the Republic of Serbia, no. 18/1993.

Rules of conduct and dress code, http://ostrajkostamenkovic.nasaskola.rs/strana/122/ PRAVILA-PONASANjA/.

Pž. 6501/2004/1, Presuda Višeg trgovinskog suda od 29.10.2004. godine.

Pž. 7528/2009 Rešenje Višeg trgovinskog suda od 22.9.2009. godine, Sudska praksa trgovinskih sudova, Bilten br. 4/2009.

Rules on driving licenses, Official Gazette of the Republic of Serbia, nos. 73/2010, 20/2019, 43/2019, 128/2020.

Rules on travel documents, Official Gazette of the Republic of Serbia, nos. 54/2008, 34/2010, $3 / 2016$.

Statute of the University of Belgrade, Gazette of the University of Belgrade, nos. 201/2018, 207/2019, 213/2020, 214/2020, 217/20.

Už-303/2017, Odluka o odbijanju Ustavne žalbe.

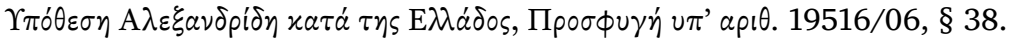

